\title{
Memes de discussão pública: o mito da conspiração comunista no Brasil'
}

Memes of public discussion: the communist conspiracy myth in Brazil

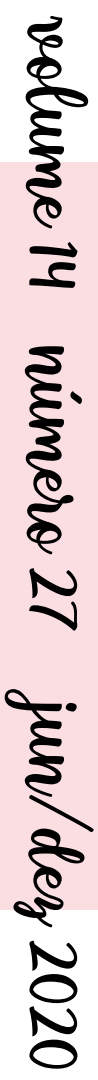

Guilherme Popolin ${ }^{2}$

gpopolin@gmail.com

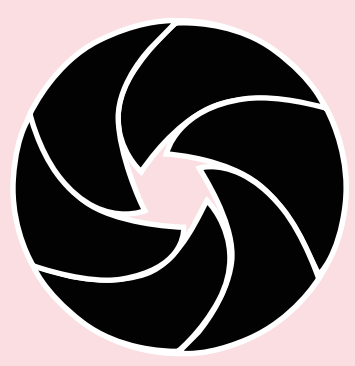

Cultura Material:

objetos, imagens e representacões - 1/2 


\section{Resumo}

Com a internet e os sites de rede social, novos recursos passaram a ser utilizados para reatualizar a ideia de um suposto complô comunista no imaginário de parte da população. A fim de investigar esse fenômeno, neste artigo, analisamos memes imagéticos de discussão pública coletados na página $O R e-$ trógrado, do Facebook, situada à direita no espectro político. A partir do percurso teórico-analítico - o qual culmina na análise de conteúdo híbrida, com aspectos quantitativos e qualitativos - demonstramos que a ideia do mito de uma conspiração comunista em curso no Brasil ganhou proeminência quando as ações do governo petista passaram a ser interpretadas a partir da lógica do comunismo. Nesse contexto, após Junho de 2013, a nova direita brasileira instrumentalizou, com eficácia, as mídias sociais, ancorando-se no anticomunismo para conquistar adeptos e alçar Jair Bolsonaro à presidência, em 2018.

Palavras-Chave: Memes imagéticos; Discussão pública; Mito; Comunismo.

\section{Abstract}

With the internet and social networking sites, new resources started to be used to update the idea of a supposed communist plot inside part of population's imaginary. In order to investigate this phenomenon, in this paper, we analyzed imagetic memes of public discussion, collected on Facebook's page 0 Retrógrado, or The Retrograde, located on the right side of the political spectrum. From the theoretical-analytical path, which culminates in the hybrid analyses content - with quantitative and qualitative aspects -, we demonstrate that the idea of a myth of a communist conspiracy is underway in Brazil gained prominence when the Workers Party government's actions became interpreted from the communism logic. In this context, after June 2013, Brazilian new-right effectively used social media, anchoring itself in anti-communism to win supporters and raise Jair Bolsonaro to the presidency in 2018.

Keywords: Imagetic memes; Public discussion; Myth; Communism.
Uma versão preliminar deste trabalho foi apresentada no Grupo de Trabalho Internet e Política (GT4) do VIII Congresso da Associação Brasileira de Pesquisadores em Comunicação e Política (VIII COMPOLÍTICA), realizado na Universidade de Brasília (UnB), de 15 a 17 de maio de 2019. A presente versão incorpora as contribuições decorrentes do debate com os pares, e integra discussões recentes acerca da problemática apresentada. O autor agradece a equipe editorial da revista Domínios da Imagem e as preciosas contribuições dos avaliadores.

2 Mestre em Comunicação pela Universidade Estadual de Londrina (UEL), Londrina (PR). Doutorando em Comunicação pelo Programa em Pós-Graduação em Comunicação da Universidade Federal Fluminense (UFF), Niterói (RJ). Integra - Laboratório de Pesquisa em Comunicação, Cultura Políticas e Economias da Colaboração (COLAB) e o \#MUSEUdeMEMES. E-mail: gpopolin@ gmail.com. 
3 Um site de rede social é uma plataforma em que os participantes se comunicam por meio de perfis de identificação única, com conteúdos produzidos pelo usuário, por outros usuários e/ou pelo sistema. As conexões entre os participantes podem ser vistas e cruzadas por outros. Os usuários podem produzir, consumir e interagir com conteúdos gerados por meio de suas conexões no site. (ELLISON \& BOYD, 2013).

4 O surgimento de uma nova direita na América Latina passa a ser investigado como um fenômeno resultante e antagônico à Maré Rosa (GIORDANO, 2014; KALTWASSER, 2014), uma vez que, por conta dos desafios impostos pelos governos inclinados à esquerda no Poder Executivo, os grupos e partidos inclinados à direita precisaram se reinventar, utilizando a internet como uma ferramenta primordial.

\section{Introdução}

Em momentos de crise, a sociedade fica mais vulnerável às explicações mitológicas, na busca de um sentido ou de uma solução para os problemas vivenciados no presente. As mídias e os aparatos comunicacionais transformaram-se com o tempo, porém, os mitos e os arquétipos, com gênese datada em um tempo imemorial, que emergem do imaginário na contemporaneidade, remetem a ideias primordiais e atemporais. A instabilidade política, econômica e social que o Brasil enfrenta, desde 2013, favorece a ebulição de mitos políticos, como o Mito da Conspiração, que atribui ao comunismo e às esquerdas brasileiras a culpa pelas mazelas enfrentadas pelo país, as quais seriam parte de uma trama conjurada com a finalidade de tomar o poder.

No Brasil, entre 2003 e 2016, anos do governo do Partido dos Trabalhadores (PT), políticas afirmativas de inclusão social e a história do partido ligada à esquerda permitiram que o imaginário de parte da sociedade brasileira compreendesse as ações do governo petista a partir da lógica do mito de uma conspiração comunista. Após Junho de 2013, a direita passou a ser mais mobilizada que a esquerda na internet (SILVEIRA, 2015), de modo que, nos últimos anos, observamos um acirramento ideológico, principalmente após as eleições presidenciais de 2014, quando a polarização política brasileira ficou nítida. O avanço da direita, sobretudo, a partir da instrumentalização dos si- tes de rede social ${ }^{3}$, endossou o processo de impeachment da ex-presidente Dilma Rousseff, em 2016 (SOUZA, 2016), culminando, em 2018, na eleição do candidato de direita, Jair Bolsonaro, para a presidência.

A fim de investigarmos esse fenômeno, inquirimos: (1) os memes de internet são instrumentalizados a fim de reatualizarem mitos políticos? (2) E de que modo o mito de uma conspiração comunista no Brasil é acionado e propagado por meio de memes imagéticos? Para tanto, analisamos memes de discussão pública, coletados na página $O$ Retrógrado, do Facebook, situada à direita no espectro político. A partir do percurso teórico-analítico, o qual culmina com a análise de conteúdo híbrida - com aspectos quantitativos e qualitativos - depreendemos, portanto, que o mito de uma conspiração comunista é reatualizado, na contemporaneidade, por meio dos memes de internet. Sendo assim, o anticomunismo é acionado como estratégia simbólica para legitimar o discurso da nova direita ${ }^{4} \mathrm{e}$ angariar apoio popular.

A fonte dos memes imagéticos coletados é a página do Facebook O Retrógrado. Por ser uma fonte on-line, sob a tutela de seus emissores e do site de rede social onde era hospedada, realizamos um backup das 2.605 imagens, o que se mostrou fundamental para o andamento da pesquisa. A página original foi excluída do site da rede social, todavia, como o objetivo deste trabalho é analisar os memes em si e não seus instrumentos de propagação ou recepção, a pesquisa não foi prejudicada. 


\section{Mitologia reatualizada}

Nos últimos anos, no Brasil, na América Latina e no mundo, a direita reagrupou-se, atualizou-se e passou a empregar novas táticas para propagar seus ideais. Como este artigo demonstra, a direita utiliza as novas tecnologias e as novas linguagens da internet para propagar velhos pensamentos, como pode ser observado com os memes de internet sobre o comunismo. De acordo com Velasco e Cruz (2015), a diferença entre a direita e a esquerda é entendida como um juízo diverso, que pode ser negativo ou positivo, sobre o ideal de igualdade no âmbito da moral e das visões de mundo: a esquerda unida pela busca de um sentimento de igualdade, contra as inúmeras desigualdades vistas pela direita como naturais e inevitáveis.

A partir de Junho de 2013 e das eleições presidenciais de 2014, o Brasil passou a enfrentar recorrentes manifestações de descontentamento, por parte da população, contra o governo. As manifestações, endossadas pelo capital financeiro e pela mídia hegemônica, legitimaram o impeachment da ex-presidente Dilma Rousseff, em 2016 (SOUZA, 2016). Nesse contexto, a internet e as mídias sociais fervilharam em debates acalorados entre a "direita" e a "esquerda". Sobre esse cenário, o Mito da Idade de Ouro, o Mito do Herói Salvador, o Mito da Conspiração e o Mito da Unidade (GIRARDET, 1987) encontraram território fértil para se propagarem por meio dos memes de internet, uma vez que a mitologia apresenta um caráter de explicação e de resolução acerca de problemas incompreendidos pelas sociedades, principalmente em momentos de crises, e se utiliza de aparatos vigentes em cada época para se reatualizar.

Os eventos da história brasileira recente reforçam um padrão de golpes e crises que, volta e meia, emperram nosso processo de evolução civilizatória. Ao longo do tempo, conspirações políticas - muitas vezes unindo aparato militar e os meios de comunicação hegemônicos - ergueram e derrubaram governos. Sendo assim, a história do comunismo no Brasil associa-se ao mito da conspiração, já que desde a criação do Partido Comunista do Brasil (PCB), em 1922, a cassação, a perseguição e a clandestinidade, decorrentes da Era Vargas (19301945), foram elementos presentes, tanto no percurso histórico do partido quanto sobre todas e todos considerados comunistas. O anticomunismo tornou-se uma das principais bandeiras levantadas pela direita (KAYSEL, 2015), sobretudo, a partir da Guerra Fria (HOBSBAWM, 2009). Em 1964, o complexo Ipes-lbad 5 selou a união dos civis com os militares, e preparou a Marcha da Família com Deus pela Liberdade, que legitimou o golpe civil-militar (SILVA, 2014), no Brasil, por parte da sociedade. $O$ golpe significou uma derrota para o Partido Comunista, que teve seus dissidentes perseguidos pela ditadura (SCHWARCZ, 2015). Dessa maneira, a propaganda anticomunista da Era Vargas 6 e do período relacionado à ditadura civil-militar formaram
Instituto Brasileiro de Ação Democrática (IBAD) e o Instituto de Pesquisas e Estudos Sociais (lpes). Organismos extrapartidários que financiavam campanhas eleitorais. Os institutos criavam e divulgavam materiais sensacionalistas que combatiam $\mathrm{O}$ comunismo, demonizando-o.

6 O Plano Cohen - criado para incriminar, perseguir e prender comunistas - é um dos exemplos mais significativos. 
as bases do mito do comunismo no Brasil, compreendido como o mito de um grande complô em curso no país.

A mensagem de um mito só é transmitida com eficácia quando existe certa disponibilidade por parte dos receptores para aceitá-la, ou seja, quando os códigos já existem no imaginário (GIRARDET, 1987). O imaginário, segundo Miguel (2004), é a base cultural de onde emergem os mitos que, em um estágio anterior à reflexão, evoca sentimentos com o intuito de explicar os acontecimentos. Desse modo, os instrumentos midiáticos da Era Vargas, os institutos de pesquisa e a imprensa, em 1964, criaram um ambiente propício para o enraizamento do mito do comunismo no Brasil e a reatualização do mito de um complô, acionando paixões e afetos presentes no imaginário. Dito isso, a crise política e econômica brasileira, intensificada após as eleições presidenciais de 2014, trouxe à tona para parte da população o medo coletivo de uma conspiração comunista. Esse medo, muitas vezes fundamentado em discursos de ódio, é externado na internet, entre outros formatos midiáticos, por meio dos memes.

Mesmo na época do ex-presidente Lula, quando a economia ia bem e o bem-estar social era ao menos aparente, o governo petista ganhava de seus opositores a alcunha de socialista e comunista, como se os dois conceitos representassem o mesmo significado, já que algumas ações do governo petista passaram a ser compreendidas a partir da lógica do mito de uma conspiração comunista. À vista disso, mesmo com a imprensa livre, com investigações contra a corrupção prendendo membros da cúpula do próprio PT - sem nenhuma intervenção dos ex-presidentes Lula e Dilma que sempre reafirmaram seus compromissos com a democracia -, o anticomunismo ganhou força.

De acordo com Ab'Sáber (2015), com o grande capital contra o governo, o brasileiro médio, antipetista e anticomunista entrou em cena na política real, "deixando de expressar privadamente um mero ressentimento rixoso, carregado de contradições, contra o relativo sucesso do governo lulo-petista" (AB'SÁBER, 2015, p. 35). De acordo com Levy e Sarmento (2020), o antipetismo foi, com efeito, endossado por um sentimento anticomunista, de modo que o termo "comunista" passou a ser comumente utilizado para se referir à esquerda em geral. Nas mídias sociais, estereótipos históricos e teorias da conspiração sugerem a influência comunista no Brasil, insinuando associações nebulosas, cuja intenção é demonstrar que todo o sistema político brasileiro está aparelhado pela esquerda.

Assim, em um contexto de convergência tecnológica, a nova direita soube instrumentalizar as mídias sociais, cooptando o brasileiro médio antipetista e se apropriando das ruas a partir dos movimentos de Junho de 2013, originalmente de esquerda - e também críticos ao governo do PT. A nova direita, nas mídias sociais, passou a ser mais mobilizada que a esquerda, com sua força fundamentada, entre ou- 
tros motivos, na associação entre os memes e o senso comum (SILVEIRA, 2015). Nesse contexto, o site de rede social Facebook permitiu que uma direita pouco expressiva no parlamento e na mídia tradicional, mas com forte capacidade de mobilizar o senso comum, expressões de ódio e preconceito, reunisse pessoas dispersas e avançasse na articulação de adeptos.

Observando esse fenômeno, depreendemos que a nova direita brasileira condensa algumas características como: o anticomunismo; o antagonismo, cuja essência está em definir o "outro", personificação de quem precisa se diferenciar; o conservadorismo; o individualismo mercadológico; a supressão histórica ou a subversão factual da realidade com uso de argumentação fake; o realismo cético que alimenta a desigualdade e a exclusão social; a aproximação de ideias totalitárias (CEPÊDA, 2018); e o alinhamento de pautas conservadoras com o neopentecostalismo (ROMANCINI, 2018).

No Brasil, de acordo com Chaloub \& Perlatto (2016), o distanciamento temporal da ditadura civil-militar, as transformações da indústria cultural, a construção de uma forte rede institucional, a habilidade de se valer dos sucessos e fracassos da esquerda e a crise do sistema partidário fizeram com que os intelectuais da nova direita ganhassem destaque no mercado editorial. De acordo com Messenberg (2017), os formadores de opinião da nova direita legitimam o anseio de uma política pautada em princípios ne- oliberais, muitas vezes aliados aos think tanks de direita em defesa do livre mercado e das privatizações. Nesse sentido, agrupamentos como o Movimento Brasil Livre (MBL) e o Vem Pra Rua (VPR) foram cruciais para a formação de uma Rede Antipetista (SANTOS, 2019), sobretudo no Facebook, ao canalizar a raiva originada nos protestos de $2013 \mathrm{em}$ direção ao PT, pavimentando o terreno para a emersão de Jair Bolsonaro como aquele que protegeria - Brasil de uma ameaça comunista, argumento que fortalece a pós-verdade propagada pelo MBL (DAVIS \& STRAUBHAAR, 2019).

A articulação com as tecnologias e a subversão do aplicativo de mensagens, WhatsApp, para fins políticos, fez com que um dos principais líderes na nova direita fosse eleito Presidente da República do Brasil, em 2018, uma vez que o bolsonarismo mostrou "(i) um esforço distribuído, capilar e voluntário visivelmente maior do que seus adversários em termos de campanha positiva e (ii) de uma visibilidade 'viral' da sua figura na internet" (CRUZ e MASSARO, 2018, p. 18). Nas próximas etapas deste trabalho, investigamos como os memes de internet são instrumentalizados a fim de reatualizarem o Mito da Conspiração, e de que modo o mito de uma conspiração comunista no Brasil é acionado em memes imagéticos de discussão pública. 
7 "(a) a group sharing common characteristics of content, form, and/ or stance, which, (b) were created with awareness of each other, and (c) were circulated, imitated, and/or transformed via the Internet by many users."

\section{Os memes e a participação política}

A ascensão da nova direita no Brasil, coroada com a eleição de Jair Bolsonaro à presidência da república, demonstra a influência da cultura popular na política contemporânea, como aponta Henry Jenkins (2013). O autor alerta sobre grupos antes silenciados pela mídia corporativa - sejam eles revolucionários, reacionários ou racistas - que passam a ter espaço nas mídias sociais para propagarem seus conteúdos. Sendo assim, a popularização das tecnologias e o uso do softwares de edição de imagens, como o Photoshop, fazem com que muitos assuntos sejam sintetizados em uma única imagem, com a possibilidade de ampla propagação na internet. As comunidades virtuais em sites de redes social, como as páginas no Facebook, criam nichos de comunicação, de acordo com o conteúdo difundido, e, com efeito, endossam a polarização política, uma vez que os sujeitos acabam por escolher ter contato apenas com os canais de comunicação de convicções e concepções políticas alinhadas às suas.

É nesse âmbito que o meme de internet ganha protagonismo na política. Segundo Viktor Chagas (2018), os memes podem ser compreendidos sob dois panoramas: no primeiro, ligado à Memética (BLACKMORE, 2000), o meme é entendido como uma unidade de reprodução cultural; no segundo, considerado por esta pesquisa, os memes de internet são compreendidos como "um acervo, um coletivo orgânico de conteúdos, de modo que só encontram sentido quando analisados em conjunto" (CHAGAS, 2018, p. 367).

A apropriação do termo "meme" - cunhado por Richard Dawkins (2007), em 1976 - define, na contemporaneidade, os conteúdos que circulam em conjunto pelas mídias sociais, isto é, segundo Limor Shifman (2014), atuando em grupos. Nesse sentido, os memes de internet são reflexos de vozes coletivas - culturais e sociais - e de vozes individuais que carregam as possibilidades de imitação e recriação. Shifman (2014) define um meme da internet como

(a) um conjunto de elementos digitais que partilham características comuns de conteúdo, forma e/ou (b) foram criados com consciência uns dos outros, e (c) foram disseminados, imitados e/ou transformados pela Internet por muitos usuários (SHIFMAN, 2014, p. 41, tradução nossa) ${ }^{7}$.

Knobel e Lankshear $(2007$ [2020]) aferiram três características predominantes entre os memes que circulam nos ambientes digitais: o humor, muitas vezes satírico, é utilizado para realizar comentários sociais; a intertextualidade, que cruza referências a artefatos e práticas da cultura popular; e a justaposição anômala, ou seja, sobreposição de imagens incongruentes. Davison (2012 [2020]) verificou que os memes tornaram-se armas retóricas sujeitas à interpretação e à variação, ao passo que podem con- 
ter camadas diversas, capazes de amalgamar questões sociais, políticas e piadas em um único artefato. De acordo com a investigação de Milner (2013 [2020]), os memes imagéticos alojam um potencial para a expressão populista e a conversação, implicando em uma possível reestilização da política.

O discurso por meio dos memes, portanto, pode ser manipulado para fins antidemocráticos. A polivocalidade e a ambivalência dos memes de internet (MILNER, 2013 [2020]) costuram referências intertextuais e interdiscursivas, ou seja, constroem conexões multimodais. Lunardi e Burgess (2020) chamam a atenção para o humor ambivalente, tipicamente brasileiro, presente nos memes nacionais. As autoras acionam o conceito de "Zoeira" para analisar o modo brasileiro de fazer humor, que é ao mesmo tempo irônico, autocrítico e autodepreciativo. A "Zoeira, nesse sentido, pode ser definida como um artefato cultural típico da comunidade brasileira, que funciona como uma alegoria e constrói a identidade do Brasil na internet e fora dela." (LUNARDI E BURGESS, 2020, p. 453).

Chagas et al. (2017) desenvolveram uma matriz taxonômica baseada em pesquisas sobre memes e em pesquisas sobre Comunicação Política. Assim, os memes políticos foram divididos em: persuasivos, os quais despertam o engajamento no próximo; de ação popular, que demonstram o engajamento ao próximo; e de discussão pública, comumente identificados como piadas. Neste trabalho, especialmente, de- bruçamo-nos sobre os memes de discussão pública, aqueles produzidos por meio de montagens visuais ou audiovisuais, frequentemente carregadas de humor e ironia.

De acordo com Chagas (2016), os memes de discussão pública possuem um humor latente. Geralmente, a construção se faz a partir de uma imagem estática com legendas sobrepostas ou com a adição de elementos característicos das fotomontagens, e "flertam com a ironia e o humor subversivo, dessacralizam e deslocam sentidos" (CHAGAS, 2016, p. 95). Chagas (2016) argumenta que "enquanto conteúdos que evocam a cultura popular-massiva, os memes podem operar como cimento da relação entre expressão individual e culturas políticas" (CHAGAS, 2016, p. 110). Para o autor, a experiência compartilhada de construção política faz com que o meme aja também como um ator de letramento político. A seguir, a análise de conteúdo mobiliza a revisão bibliográfica, com o intuito de apurar como ocorre a articulação entre o mito de uma conspiração comunista e os memes de internet compartilhados no Facebook. 
8 ○ vocábulo blue tem acepções diferentes daquelas do correspondente direto em português, azul. Por esse motivo, optamos por não traduzir os excertos da transcrição de "Blue" (JARMAN, 1993). Disponível em: https:// queerculturalcenter.org/derek-jarman. Acesso em: 07 mai. 2020.

\section{O comunismo e os memes}

A partir do arcabouço teórico, lançamos luz sobre o corpus desta pesquisa, a fim de compreendermos como os memes de internet são instrumentalizados para reatualizarem mitos políticos, e de que modo o mito de uma conspiração comunista no Brasil é acionado e propagado por meio deles. A análise de conteúdo (HSIEH \& SHANNON, 2005) é híbrida, com aspectos quantitativos e qualitativos, e operacionalizada a partir dos tipos de humor no Facebook propostos por Taecharungroj \& Nueangjamnong (2015), como o humor de comparação, o humor de personificação, o humor de exagero, o humor de trocadilho, o humor sarcástico, o humor nonsense e o humor surpresa. Para tanto, coletamos, com a extensão DownAlbum para o navegador Google Chrome, 2.947 imagens postadas pela página $\bigcirc$ Retrógrado, no site de rede social Facebook, no período de 17/07/2016 até 18/08/2017.

Do total de 2.947 arquivos, imagens repetidas e imagens de cunho publicitário foram deletadas. Restaram 2.605 imagens, das quais 2.322 foram enquadradas previamente como memes de internet pertencentes a um dos quatro conjuntos mitológicos identificados por Raoul Girardet (1987): a Conspiração, a Era de Ouro, o Herói Salvador e a Unidade. Entre os memes coletados, 670 foram catalogados como pertencentes ao conjunto da Conspiração, 129 foram catalogados ao conjunto mitológico da Era de Ouro, 136 ao conjunto do Herói Sal- vador e 1.419 ao conjunto da Unidade. Dessa maneira, a catalogação proporcionou um recorte analítico mais específico, de modo que, neste artigo, apresentamos uma visão panorâmica sobre os 34 memes de discussão pública sobre o comunismo, identificados entre os 670 concernentes ao conjunto da Conspiração, e exemplificados pelas figuras a seguir.

Dos 34 memes de discussão pública sobre o comunismo, onze utilizam o humor de comparação, ao combinar dois elementos diferentes, a fim de produzir uma situação engraçada. Os memes (Imagem 01) se enquadram entre os memes de discussão pública, pois o humor de comparação utiliza-se de estereótipos e do senso comum da cultura popular acerca do comunismo. A analogia feita de forma simplista não leva em consideração os contextos históricos, tampouco as vertentes que o comunismo ganhou ao longo do tempo.

Imagem 01 - Humor de comparação

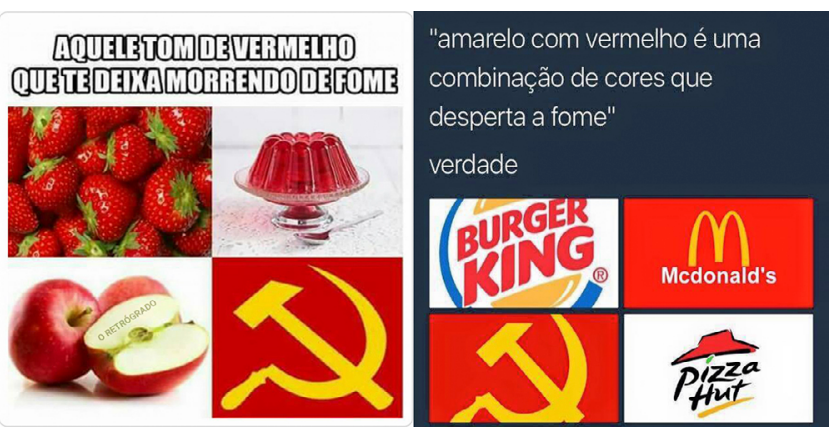

Fonte: Acervo do autor

Os memes (Imagem 01) remetem a eventos históricos da ex-URSS e da China, os quais tiveram a fome no centro de crises. Segundo Robé- 
rio Rodrigues (2006), durante a Guerra Civil da Rússia (1918-1921) - período em que o Partido Comunista já estava à frente do país após a revolução de 1917 - a fome se alastrou pelo país. A política de requisições dos excedentes dos camponeses na qual estes deveriam entregar, ao Estado, a colheita remanescente, reduziu a quantidade para consumo próprio e fez com que muitos escondessem os estoques para vender no mercado ilegal.

Na década de 1930, no período da autocracia stalinista, os camponeses se rebelaram contra a coletivização forçada. A destruição de cereais, equipamentos e 0 fuzilamento dos que discordavam do governo geraram uma nova crise, a qual foi acompanhada de um período de fome generalizada entre os camponeses (RODRIGUES, 2006). A China, comandada por Mao Tsé-Tung, também enfrentou um período de grande fome entre 1959 e 1961. As inundações, a coletivização forçada da agricultura, as metas irrealistas de produção industrial e a ênfase na indústria pesada impactaram de forma negativa a produção agrícola. A falta de bens de consumo básico, como os alimentos, foi uma consequência dessa conjuntura (MORAIS, 2011).

A fome, como indica os memes (Imagem 01), não é uma característica do comunismo. No caso da ex-URSS e da China, os desastres em relação à alimentação da população são relacionados principalmente à política com foco nas indústrias pesadas e à repressão dos camponeses. Conforme Netto (1987), tais aspectos nada têm a ver com o comunismo proposto por Marx e Engels, sendo assim, fazem parte da história de países que almejaram o comunismo, mas seguiram um caminho obscuro ainda na fase do socialismo - momento de transição entre o capitalismo e o comunismo.

Imagem 02 - Humor de personificação

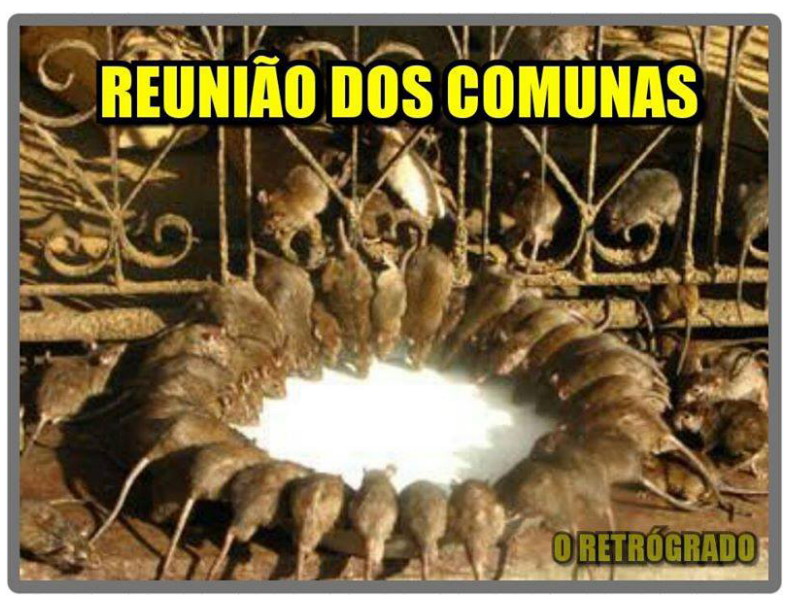

Fonte: Acervo do autor

O meme (Imagem 02) reproduz um estereótipo histórico perpetuado pelos opositores dos ideais comunistas. Assim sendo, entendemos que o emissor do meme buscou comparar os comunistas com ratos, os quais são personificados com o apoio do texto verbal sobre a imagem. O conteúdo do único exemplar do corpus, a acionar o humor de personificação, mostra-nos a organização e a realização de uma reunião, características humanas imputadas sobre um grupo organizado de animais.

Uma reunião realizada por ratos pode ser relacionada com a organização de pessoas que possuem hábitos degradantes e que vivem próximas da sujeira, simbolizan- 
do uma ameaça de contaminação, aspectos que estão no cerne do Mito da Conspiração (GIRARDET, 1987). A associação dos comunistas com ratos reflete o caráter clandestino que o Partido Comunista e seus adeptos enfrentaram ao longo da história do Brasil, além de endossar a desumanização das pessoas consideradas comunistas, o que ratifica a perseguição e o extermínio.

Imagem 03 - Humor de Exagero
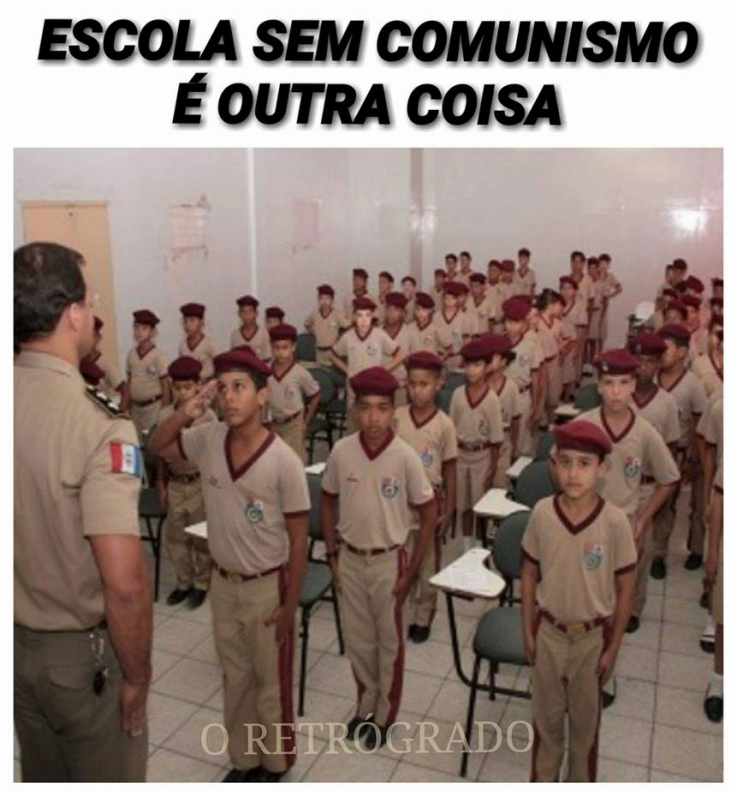

Fonte: Acervo do autor

Dos três memes concernentes ao humor de exagero, o exemplo da Imagem 03 demonstra como ocorre o redimensionamento do conteúdo emitido, para além da realidade, neste caso, presente no âmbito da educação escolar. Compreendemos que, com as ações do PT vistas sob a ótica do comunismo, o trabatho do partido na educação passou a compor o imaginário de uma conspiração, na qual os estudantes estariam sendo doutrinados em sala de aula. A suposta doutrinação sobre variados aspectos do universo social, mas também em prol do comunismo, levou à criação de um projeto de lei chamado Escola Sem Partido, apoiado por segmentos da sociedade que acreditam que as instituições de ensino - abrangendo as instâncias do ensino infantil até o ensino superior - seriam mais ordeiras e eficientes sem a influência do comunismo que visa doutrinar os estudantes a favor do PT e das esquerdas.

Ademais, com a implantação de políticas afirmativas, como a Lei das Cotas, entendemos que grupos ligados à direita no espectro político passaram a compreender essas ações inclusivas como ações comunistas. Nesse caso, fica evidente o poder da recusa ligado ao pensamento da direita política, representado pelos posicionamentos antipartidário e anticotas sobre a educação. Depreendemos que, ao adotar tais posicionamentos sobre um assunto de interesse público como a educação, a direita reforça as desigualdades tidas por ela como naturais e inevitáveis, com o objetivo de manter o status quo, econômico e social, resquícios do período colonial, perpetuando a lógica escravocrata ainda vigente na sociedade brasileira (SOUZA, 2019).

Imagem 04 - Humor de trocadilho

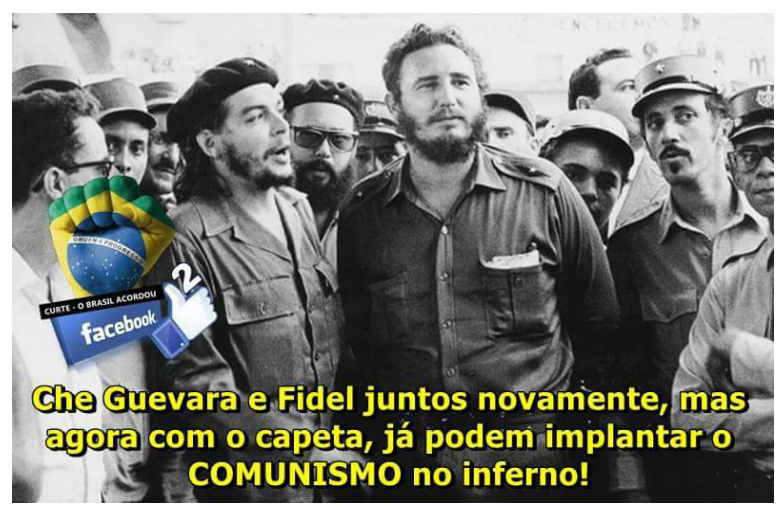

Fonte: Acervo do autor 
O humor de trocadilho utiliza elementos da linguagem para criar significados, muitas vezes incomuns. Dos quatro memes coletados, que apresentam esse tipo de humor, o exemplo acima (Imagem 04) é significativo por trazer uma foto de Fidel Castro e Che Guevara - dada a circunstância da morte de Fidel Castro, o meme satiriza o fato com uma retórica agressiva. Na Imagem 04, em busca de provocar o humor, observamos a utilização do trocadilho com a linguagem, efeito que provavelmente atinge aqueles que concordam com os conteúdos emitidos pela página $\bigcirc$ Retrógrado. Dessa maneira, cria-se um espírito de combate, já que o imaginário daqueles que veem os comunistas como inimigos, os quais merecem ser eliminados, é alimentado por essa espécie de meme.

Imagem 05 - Humor sarcástico

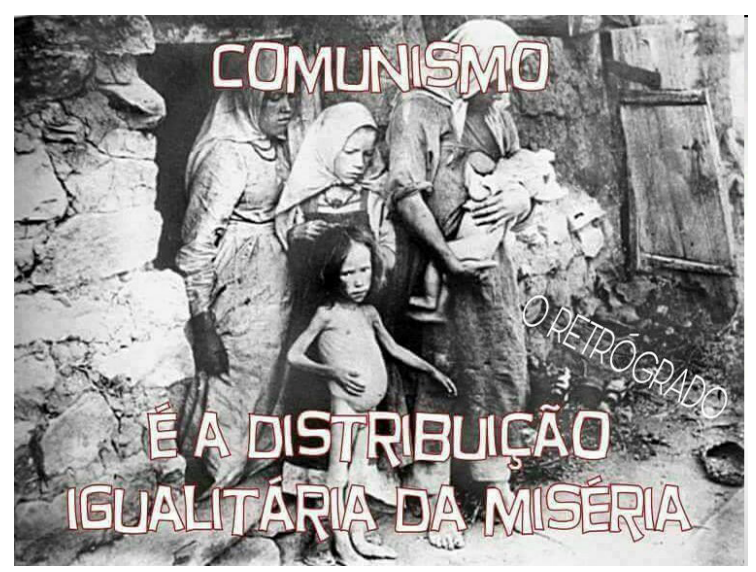

Fonte: Acervo do autor

O meme (Imagem 05) enquadra-se no humor sarcástico, ao utilizar a imagem de uma família durante o Holodomor (1932-1933), popularmente chamado de "holocausto ucraniano", causado pelas políticas do governo soviético. Na ocasião, Stalin bloqueou a entrada de alimentos na Ucrânia, o que levou muitas pessoas a morrerem de fome. O humor sarcástico é identificado pela união do texto verbal sobre a imagem, uma vez que, com a interpretação do contexto que é retratado, é possível perceber o estilo agressivo de humor empregado. Dessa maneira, entendemos que o emissor, ao querer propagar sua mensagem para atacar o comunismo, também desrespeita e banaliza as vítimas do Holodomor. Entre os cinco memes coletados, e que apresentam o humor sarcástico, verificamos que o meme (Imagem 05), de acordo com o contexto da política contemporânea no Brasil, ratifica a associação do comunismo com a fome, com o que é degradante e com o que é sub-humano.

\section{Imagem 06 - Humor nonsense}

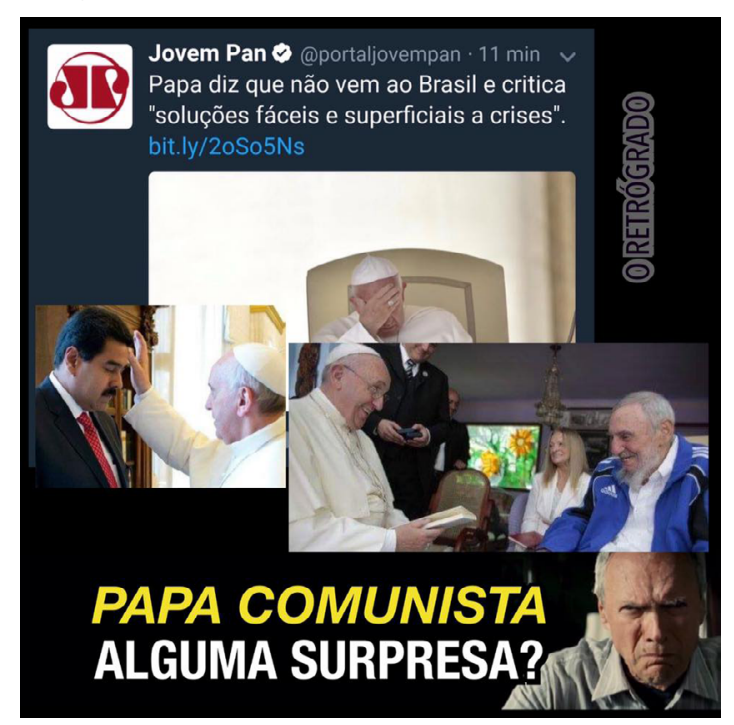

Fonte: Acervo do autor

Por vezes, a retórica que fomenta o medo de uma ameaça comunista, calcada no senso comum, soa incoerente. Entre os 34 
1 De acordo com Bernardet (1980), o Primeiro Plano (PP) é um enquadramento que mostra o personagem a partir do busto; o Primeiríssimo Plano (PPP), mais fechado, mostra o rosto inteiro; e o Plano de Detalhe, mais fechado ainda, concentra-se em uma parte menor do corpo. memes de discussão pública sobre - comunismo, quatro apresentam o humor nonsense, como observamos na situação absurda, da Imagem 06, que retrata o Papa Francisco como comunista, uma vez que a Igreja Católica, como instituição, é historicamente oposta ao comunismo. Muitas vezes, a nova direita interpreta as falas e ações do papa, líder mundial da Igreja Católica Romana e Chefe de Estado do Vaticano, como comunistas, de acordo com a mesma lógica que compreende o governo do PT como comunista: políticas em prol dos direitos humanos e ações afirmativas interpretadas como práticas comunistas em oposição às práticas capitalistas, que abrangem, por exemplo, o individualismo e a meritocracia.

Imagem 07 - Humor surpresa

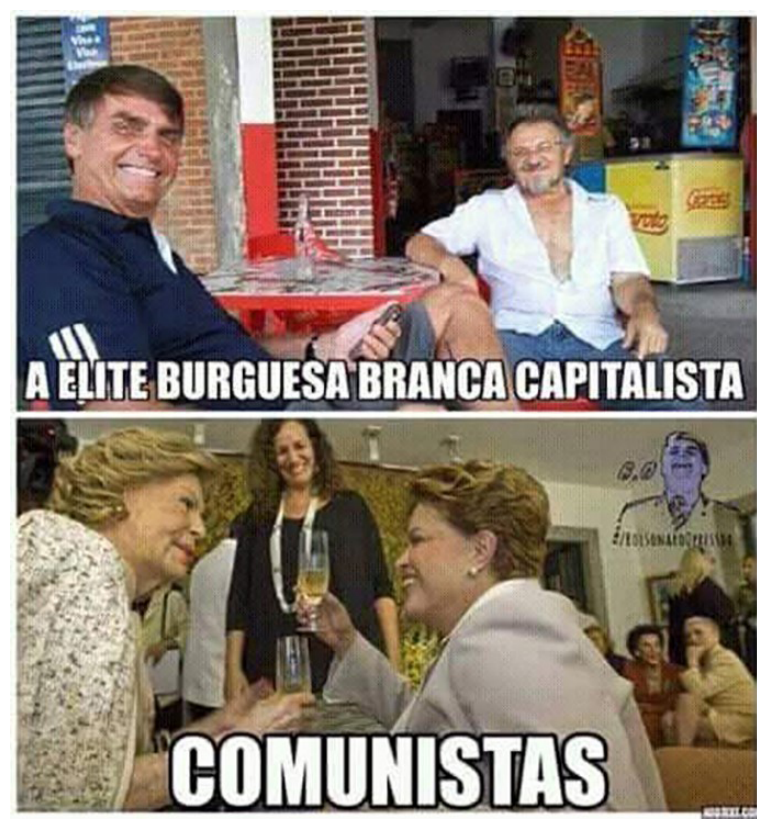

Fonte: Acervo do autor

A surpresa do meme (Imagem 07) está na contraposição das imagens e dos textos verbais sobre elas, ao brincar com a inversão dos este- reótipos, em que os homens brancos estão em um local simples e duas mulheres de partidos de esquerda estão tomando champanhe com a esposa do ex-dono do $17^{\circ}$ maior conglomerado de mídia do mundo, hoje, Grupo Globo. Observamos que a montagem desse meme reforça o caráter do elemento surpresa, contribuindo para subverter a lógica do que é ser comunista para o senso comum, isto é, partilhar a pobreza.

Fica evidente que o emissor do meme associa a ex-presidente Dilma Rousseff (PT) e Lily Marinho ao comunismo, principalmente por conta da presença da deputada federal Jandira Feghali, do Partido Comunista do Brasil (PCdoB), no mesmo meme. Entre os seis memes coletados que apresentam o humor surpresa, na Imagem 07 o recurso é acionado para ratificar a ideia de que há uma conspiração entre os comunistas com as elites, simbolizada pelo brinde em uma reunião privada. Seguindo essa lógica, a elite burguesa branca e capitalista estaria ao lado do povo, com o objetivo de desmantelar o arranjo entre os comunistas, e assim, cessar a dominação.

De acordo com Girardet (1987), no Mito da Conspiração, um grupo ameaçador é responsável por um complô, o qual fomenta as mazelas sociais, atentados e desordens. A partir dos memes analisados, compreendemos como o comunismo passou a ser demonizado intensamente, sobretudo, com o agravamento da crise política brasileira. $O$ termo comunista passou a ser sinôni- 
mo de esquerda para muitas pessoas, sempre associado à destruição da família tradicional brasileira, à corrupção, à fome, à violência e ao suposto complô para a implantação de uma ditadura comunista no Brasil. Assim, uma aura ameaçadora é colocada sob as pessoas com afinidades políticas aos pensamentos de esquerda, imigrantes, LGBTs e minorias políticas em geral.

Portanto, a realidade é agregada ao mito a partir de conexões com dados factuais, verificáveis e apreensiveis. Por meio de uma lógica de fatos reduzidos, o mito da conspiração, ou complô, preenche a função social de explicação. Aparentemente inflexível, essa lógica faz com que a causa ou o assunto temido ceda "diante de um sistema organizado de evidências novas. $O$ destino volta a ficar inteligível; uma certa forma de racionalidade (...) tende a restabelecer-se no curso desconcertante das coisas..." (GIRARDET, 1987, p. 55). Os memes analisados podem ser compreendidos a partir da definição de Aumont (2002) para a imagem, ou seja, um conjunto de significantes, visto que a partir de uma perspectiva simbólica ligada ao imaginário, a interação do sujeito com a imagem pode ser contraditória, já que:

[...] além da capacidade perceptiva, entram em jogo o saber, os afetos, as crenças, que por sua vez, são muito modelados pela vinculação a uma região da história (a uma classe social, a uma época, a uma cultura). (AUMONT, 2002, p. 77).
Desse modo, a criação de memes, sobretudo no formato image macros $^{8}$, pode ser observada como "um imperativo estético da era digital" (OLIVEIRA, 2016, p. 152). De acordo com a pesquisa de Oliveira (2016), W. J. T. Mitchell propõe a substituição da reprodução técnica, de Walter Benjamin, pela reprodução biocibernética, ao levar em consideração a velocidade dos processos de reprodução das imagens digitais, as quais podem ser acrescidas de texto, como o image macros. Sendo assim, os memes de internet analisados configuram-se como imagens sintéticas digitais que, segundo Hans Belting (2007), expressam um novo conceito para a compreensão das imagens e uma nova práxis da percepção.

Como é característico dos memes de discussão pública, a construção simbólica observada tensiona imagens e legendas sobrepostas a fim de provocar o humor. Constatamos, a partir dos memes analisados, que o imaginário acerca do comunismo é aguçado por meio da associação entre o Mito da Conspiração e o contexto brasileiro, uma vez que os mitos possuem um caráter ambíguo e sua função de explicação tem a missão de ordenar o caos perante os acontecimentos, em busca da compreensão do presente (CAMPBELL, 2016). Sendo assim, mesmo quando os memes não remetem diretamente ao contexto brasileiro, os exemplares analisados funcionam como um alerta contra o comunismo, movimentando paixões e emoções comuns na internet, condição que, na cultura digi-
8 "Correspondem a uma indefectível estrutura imagética-textual que dentro dessa dialética carrega uma qualidade icônica" (OLIVEIRA, 2016, p. 97. Grifo do autor). Muitas vezes confundido como $\mathrm{O}$ único modelo de meme possível, por ser o mais antigo e mais clássico. 
tal, proporciona a reatualização de mitos políticos (MAFFESOLI, 2009).

\section{Considerações finais}

A partir de Junho de 2013 e da eleição presidencial de 2014, instaurou-se no Brasil um ambiente de crise política que culminou no impeachment da ex-presidente Dilma Rousseff e, posteriormente, na eleição do representante da direita, Jair Bolsonaro, em 2018. Nesse contexto, os movimentos da nova direita emergiram na internet e passaram a utilizar a lógica comunista para julgar as ações do PT e da esquerda de modo geral.

Em um momento no qual os sites de rede social revelam-se como plataformas para a construção de narrativas e disputas políticas, os memes de internet são estrategicamente acionados, visto que cada época apresenta maneiras diferentes de criação, de reprodução e de renovação do imaginário. Na contemporaneidade, os memes oportunizam a criação de uma identidade coletiva, como mostramos em relação à nova direita, agrupamento político que tem o anticomunismo como um de seus pilares fundantes.

A internet estimula a participação política de parte da população, para além do voto ou da afiliação a alguma organização, com a apropriação de imagens e da edição delas como parte do processo. Essa participação, foge dos moldes formais e enfraquece as instituições (CASTELLS, 2018), ao passo que, por meio da influência da cultura popular, integra e socializa os sujeitos com a linguagem política. Nesse sentido, o meme de internet pode funcionar como um agente de letramento político (CHAGAS, 2016), aspecto que aponta caminhos para futuras pesquisas em comunicação, destrinchando o restante do material coletado.

Nossa investigação, a partir dos memes políticos de discussão pública, coletados na página de direita, O Retrógrado, do Facebook, mostrou-nos que os memes de internet são instrumentalizados a fim de reatualizarem mitos políticos. O mito de uma conspiração comunista no Brasil é acionado e propagado por meio de memes imagéticos, que endossam a suposta índole ameaçadora do comunismo, o qual precisa ser combatido. O humor e a ironia são utilizados para reforçar o caráter marginal que foi imputado ao comunismo no decorrer da história do Brasil, visto que aos comunistas são atribuídas características recuperadas da Era Vargas, da ditadura civil-militar e da Guerra Fria.

Observamos que os memes analisados partilham uma característica de conteúdo preponderante: o comunismo como chave retórica, a partir da qual são estabelecidas articulações irônicas e humorísticas as quais são comuns em memes de discussão pública. Por meio da sátira e da justaposição de imagens, os memes cruzam referências históricas e da cultura popular, evidenciando o componente intertextual 
das peças analisadas. O formato image macro, quando a imagem é sobreposta por texto, expõe a polivocalidade e o caráter multimodal característicos dos memes de internet.

A ambivalência, comum aos memes e aos mitos, é um componente importante na sustentação do conjunto de peças analisadas, uma vez que esta característica garante a aderência da mensagem propagada de acordo com a propensão de seus interlocutores. Ou seja, o mito de um complô pode ser acionado por diversos campos do espectro político, todavia, como os memes analisados foram emitidos por aqueles que se identificam com pautas conservadoras e de direita, compreendemos que o sentido da mensagem mitológica é deslocado a fim de ratificar o senso comum e as ideias preestabelecidas no imaginário.

Depreendemos um deslocamento de sentido, ao compreendermos que estereótipos como o da fome, da agressividade e o da pobreza, associados ao comunismo, reforçam o medo de seus interlocutores em relação a um eventual governo comunista, sistema que reside no imaginário da direita como total negação a qualquer tipo de realização democrática, assim sendo, um suposto fracasso global dos regimes comunistas é acionado para malograr o PT e a esquerda brasileira.

Segundo José Paulo Netto (1987), a proposta do comunismo é a igualdade total entre todas as pessoas de uma sociedade. Essa igualdade diz respeito às oportunidades sociais que uma pessoa possa ter para desenvolver sua personalidade. É diferente do que é propagado pelo senso comum: a ideia de que o comunismo visa tornar todos os cidadãos iguais a nível de suas identidades e subjetividades. Cabe ressaltar aqui o ideal ético comunista, o qual propõe uma nova comunidade humana desenvolvida sob um viés humanista. Com a supressão das classes sociais e com o proletariado dirigindo a democracia, a opressão e a exploração tornam-se inexistentes com o comunismo aos moldes de Marx e Engels, sendo assim, o significado de pobreza da forma como é utilizado nas sociedades capitalistas, principalmente para se referir à posse de dinheiro ou bens de consumo, esvazia-se com o comunismo.

Apuramos que os comunistas são vistos como aqueles que agem de maneira organizada e clandestina - aspectos endossados pela história, e que ratificam a ebulição do Mito da Conspiração (GIRARDET, 1987). Como vimos neste artigo, a ideia do comunismo, acoplado ao mito de uma conspiração, perdura até a contemporaneidade, utilizando-se dos memes de internet como agentes em sua reatualização. Elementos imagéticos associados a textos verbais, o senso comum e os estereótipos fazem com que os memes políticos de discussão pública contribuam para que o mito político do comunismo seja fomentado e reatualizado.

Os memes de discussão pública analisados, por serem frequentemente identificados como piadas 
por um determinado grupo, colaboram para o fortalecimento de solidariedades preconceituosas e conservadoras. A página $O$ Retrógrado, fonte dos memes coletados para esta pesquisa, expunha o radicalismo da nova direita em analogias carregadas de senso comum e estereótipos, cumprindo o papel de explicação para aqueles que buscam compreender o presente por meio de uma lógica conservadora e reacionária. 


\section{Referências}

AB'SÁBER, Tales. Dilma Rousseff e o ódio político. São Paulo: Hedra, 2015.

AUMONT, Jacques. A imagem. Campinas, São Paulo: Papirus, 2004.

BELTING, Hans. Antropología de la imagen. Madrid: Katz Editores, 2007.

BLACKMORE, Susan. The power of memes. Scientific American, v. 283, n. 4, p. $52-61,2000$.

CAMPBELL, Joseph. O poder do mito. São Paulo: Palas Athena, 2016.

CASTELLS, Manuel. Ruptura: a crise da democracia liberal. Rio de Janeiro: Zahar, 2018.

CEPÊDA, Vera Alves. A nova direita no Brasil: contexto e matrizes conceituais. Mediações - Revista de Ciências Sociais, v. 23, n. 2, p. 40-74, 2018.

CHAGAS, Viktor. "NÃO TENHO NADA A VER COM ISSO": cultura política, humor e intertextualidade nos memes das Eleições 2014. In: CERVI, Emerson; MASSUCHIN, Michele; CARVALHO, Fernanda C. de (org.). Internet e Eleiçōes no Brasil. Curitiba: CPOP (grupo de pesquisa em Comunicação Política e Opinião Pública), 2016.

CHAGAS, Viktor. A febre dos memes de política. Revista Famecos - mídia, cultura e tecnologia, v. 25, n. 1, p. 1-26, 2018.

CHAGAS, Viktor; FREIRE, Fernanda; RIOS, Daniel; MAGALHÃES, Dandara. A política dos memes e os memes da política: proposta metodológica de análise de conteúdo de memes dos debates eleitorais de 2014. Intexto, n. 38, p. 173-196, 2017.

CHALOUB, Jorge; PERLATTO, Fernando. A nova direita brasileira: ideias, retórica e prática política. Insight Inteligência, ano 19, n. 72, p. 24-41, 2016.

CRUZ, Francisco Brito; MASSARO, Heloisa. Você na Mira - InternetLab: Relatório \#2 Um raio-X do marketing digital dos presidenciáveis. 2018. Disponível em: https://www.internetlab.org.br/wp-content/uploads/2018/09/Relat\%c3\%b3rio-Voc\%c3\%aa-na-Mira-2.pdf. Acesso em: 20 set. 2020. 
DAVIS, Stuart; STRAUBHAAR, Joe. Producing Antipetismo: Media activism and the rise of the radical, nationalist right in contemporary Brazil. International Communication Gazette, v. 82, n. 1, p. 82-100, 2020.

DAVISON, Patrick. A linguagem dos memes de internet (dez anos depois). In: CHAGAS, Viktor (org.) A cultura dos memes: aspectos sociológicos e dimensões políticas de um fenômeno do mundo digital, p. 139-156. Salvador: Editora da UFBA, 2020.

DAWKINS, Richard. O gene Egoísta. São Paulo: Companhia das Letras, 2007.

ELLISON, Nicole B.; BOYD, Danah. Sociality through Social Network Sites. In: DUTTON, William. H. (Org.). The Oxford Handbook of Internet Studies. Oxford: Oxford University Press, 2013.

GIORDANO, Verónica. ¿Qué hay de nuevo en las "nuevas derechas?. Nueva Sociedad, n. 254, p. 46-56, 2014.

GIRARDET, Raoul. Mitos e mitologias políticas. São Paulo: Companhia das Letras, 1987.

HOBSBAWM, Eric. Era dos Extremos: O breve século XX, 1914-1991. São Paulo: Companhia das Letras, 2009.

HSIEH, Hsiu-Fang; SHANNON, Sarah E. Three Approaches to Qualitative Content Analysis. Qualitative Health Research, v. 15, n. 9, p. 1277-1288, 2005.

JENKINS, Henry. Cultura da convergência. São Paulo: Aleph, 2013.

KALTWASSER, Cristóbal Rovira. La derecha en América Latina y su lucha contra la adversidad. Nueva Sociedad, n. 254, p. 34-45, 2014.

KAYSEL, André. Regressando ao Regresso: elementos para uma genealogia das direitas brasileiras. In: Direita, volver!: o retorno da direita e o ciclo político brasileiro. São Paulo: Editora Fundação Perseu Abramo, 2015.

KNOBEL, Michele; LANKSHEAR, Colin. Memes on-line, afinidades e produção cultural (2007-2018). In: CHAGAS, Viktor (org.) A cultura dos memes: aspectos sociológicos e dimensões políticas de um fenômeno do mundo digital, p. 179-285. Salvador: Editora da UFBA, 2020.

LEVY, Helton; SARMENTO, Claudia. Understanding Viral Communism: A Thematic Analysis of Twitter During Brazil's 2018 Elections. Westminster Papers in Communication and Culture, v. 15, n. 1, p. 19-36, 2020. 
LUNARDI, Gabriela; BURGESS, Jean. "É zoeira": as dinâmicas culturais do humor brasileiro na internet. In: CHAGAS, Viktor (org.) A cultura dos memes: aspectos sociológicos e dimensões políticas de um fenômeno do mundo digital, p. 427-458. Salvador, BA: Editora da UFBA, 2020.

MAFFESOLI, M. Iconologías: Nuestras idolatrías pós-modernas. Barcelona: Península, 2009.

MESSENBERG, Débora. A direita que saiu do armário: a cosmovisão dos formadores de opinião dos manifestantes de direita brasileiros. Revista Sociedade e Estado, v. 32, n. 3, p. 621-647, 2017.

MIGUEL, Luís Felipe. Mito político. In: RUBIM, Antonio Albino Canelas (Org.). Comunicação e política: conceitos e abordagens. Salvador: Edufba, 2004.

MILNER, Ryan M. Polivocalidade pop: memes de internet, participação pública e o movimento Occupy Wall Street. In: CHAGAS, Viktor (org.) A cultura dos memes: aspectos sociológicos e dimensões políticas de um fenômeno do mundo digital, p. 179-220. Salvador: Editora da UFBA, 2020.

MORAIS, Isabela Nogueira. Desenvolvimento Econômico, Distribuição de Renda e Pobreza na China Contemporânea. 201 1. Tese (Doutorado em Ciências Econômicas) - Instituto de Economia da Universidade Federal do Rio de Janeiro, Rio de Janeiro. 201 1, 209 f. Disponível em: https://www.academia.edu/21529776/Desenvolvimento Econ\%C3\%B4mico Distribui\%C3\%A7\%C3\%A30 de Renda e Pobreza na China Contempor\%C3\%A2nea Instituto de Economia Universidade Federal do Rio de Janeiro 2011. Acesso em 06 out. 2020.

NETTO, José Paulo. O que todo cidadão precisa saber sobre comunismo. São Paulo: Global, 1987.

OLIVEIRA, Juracy. A imagem técnico-memética no Facebook. 2016. Dissertação (Mestrado em Comunicação) - Faculdade de Comunicação Social, Universidade do Estado do Rio de Janeiro, Rio de Janeiro, 2016. 163 f. Disponivel em: http://www.ppgcom.verj.br/wp-content/uploads/Disserta\%C3\%A7\%C3\%A30-Juracy-Pinheiro.pdf. Acesso em: 06 out. 2020.

RODRIGUES, Robério Paulino. O colapso da URSS: um estudo das causas. 2006. 310 f. Tese (Doutorado em História Econômica) - Pós-Graduação em História Econômica, Universidade Estadual de São Paulo, São Paulo, 2006. Disponível em: http://www.teses.usp.br/teses/disponiveis/8/8137/tde-11072007-112541/ pt-br.php. Acesso em: 06 out. 2020.

ROMANCINI, Richard. Do "Kit Gay" ao "Monitor da Doutrinação": a reação conservadora no Brasil. Contracampo, Niterói, v. 37, n. 02, p. 87-108, 2018. 
SANTOS, Marcelo Alves dos. \#Vaipracuba!: A gênese das redes de direita no Facebook. Curitiba: Appris, 2019.

SCHWARCZ, Lilia Moritz. Brasil: uma biografia. São Paulo: Companhia das Letras, 2015.

SHIFMAN, Limor. Memes in Digital Culture. London: MIT Press, 2014.

SILVA, Juremir Machado da. 1964: Golpe Midiático-Civil-Militar. Porto Alegre: Editora Sulina, 2014.

SILVEIRA, Sergio Amadeu da. Direita nas redes sociais online. In: Direita, volver!: o retorno da direita e o ciclo político brasileiro. São Paulo: Editora Fundação Perseu Abramo, 2015.

SOUZA, Jessé. A elite do atraso. Rio de Janeiro: Estação Brasil, 2019.

SOUZA, Jessé. A radiografia do golpe: entenda como e por que você foi enganado. Rio de Janeiro: LeYa, 2016.

TAECHARUNGROJ, Viriya.; NUEANGJAMNONG, Pitchanut. Humour 2.0: styles and types of humour and virality of memes on Facebook. Journal of Creative Communications, v. 10, n. 3, p. 288-302, 2015.

VELASCO E CRUZ, Sebastião; KAYSEL, André; CODAS, Gustavo (Org.). Direita, volver!: o retorno da direita e o ciclo político brasileiro. São Paulo: Editora Fundação Perseu Abramo, 2015.

Recebido em: 7/out/2020

Aceito em: 18/dez/2020 